\title{
Kematian Akibat Pneumonia Berat pada Anak Balita
}

\author{
Diah Asri Wulandari, Sri Sudarwati, Adi Utomo Suardi, Reni Ghrahani D. M., \\ Cissy B. Kartasasmita \\ Departemen Ilmu Kesehatan Anak Fakultas Kedokteran Universitas Padjadjaran \\ Rumah Sakit Dr. Hasan Sadikin Bandung
}

\begin{abstract}
Abstrak
Pneumonia merupakan penyebab utama kesakitan dan kematian pada anak, terutama di negara berkembang. Angka kematian karena pneumonia di negara berkembang 10-15 kali lebih tinggi daripada di negara maju. Penelitian ini bertujuan untuk mengetahui angka kematian dan faktor risiko pada anak balita yang dirawat di rumah sakit karena pneumonia. Penelitian potong lintang ini dilakukan pada anak usia 1-59 bulan yang dirawat di Rumah Sakit Dr. Hasan Sadikin Bandung karena pneumonia periode November 2007-Januari 2009. Tiga ratus delapan belas anak ikut serta dalam penelitian ini. Usia median anak 11,6 bulan, sebanyak $237(74,5 \%)$ di antaranya berusia $\leq 12$ bulan. Sembilan puluh tiga $(29,2 \%)$ anak didiagnosis pneumonia sangat berat dan $225(70,8 \%)$ anak pneumonia berat. Dua puluh tiga $(7,2 \%)$ penderita meninggal selama perawatan, 20 di antaranya dirawat dengan pneumonia sangat berat $(\mathrm{p}<0,001$; OR 20,274; 95\%IK: 5,855-70,197). Kelainan jantung bawaan $(\mathrm{p}=0,002$; OR 5,795; 95\%IK: 2,115-15,407) dan leukositosis $\left(\geq 15.500 / \mathrm{mm}^{3} ; \mathrm{p}=0,002\right.$; OR 3,879; 95\% erat dengan kematian. Kuman patogen ditemukan pada 11 dari 23 penderita yang meninggal. Simpulan, kematian karena pneumonia berat masih cukup tinggi. Pneumonia sangat berat, kelainan jantung bawaan, dan leukositosis merupakan faktor risiko yang meningkatkan kematian anak balita dengan pneumonia. [MKB. 2013;45(1):50-5]
\end{abstract}

Kata kunci: Balita, faktor risiko, kematian, pneumonia

\section{Mortality Due to Severe Pneumonia in Under-Five Years Old Children}

\begin{abstract}
Pneumonia is one of the leading causes of morbidity and mortality in children, mainly in developing countries with a 10-15 times higher mortality rate than developed countries. The aim of the study was to know the mortality rate and its risk factors among under five years old children who were hospitalized due to severe pneumonia. This cross-sectional study was conducted to 1 to 59 months old children with pneumonia at the Department of Pediatric Dr. Hasan Sadikin Bandung Hospital from November 2007 to January 2009. Three hundred and eighteen children were enrolled in this study. The median age was 11.16 months, and $237(74.5 \%)$ were $\leq 12$ months of age. Very severe pneumonia was diagnosed in $93(29.2 \%)$ and severe pneumonia in $225(70.8 \%)$ children. Twenty three $(7.2 \%)$ children died during hospitalization, 20 were hospitalized with very severe pneumonia $(\mathrm{p}<0.001, \mathrm{OR}$ 20.274, 95\%CI: 5.855-70.197). Congenital heart disease ( $p=0.002$, OR 5.795, 95\%CI: 2.115-15.407) and leucocytosis $\left(\geq 15,500 / \mathrm{mm}^{3}, \mathrm{p}=0.002\right.$, OR $\left.3.879,95 \% \mathrm{CI}: 1.547-9.727\right)$ were significantly associated to the mortality. Pathogenic bacteria were identified in 11 of 23 patients. In conclusions, the mortality of severe pneumonia is still high. Very severe pneumonia, congenital heart disease and leucocytosis are factors that increase mortality among under-five years old children with pneumonia. [MKB. 2013;45(1):50-5]
\end{abstract}

Key words: Mortality, pneumonia, risk factor, under five years old children

Korespondensi: Diah Asri Wulandari dr., Sp.A, Departemen Ilmu Kesehatan Anak Fakultas Kedokteran Universitas Padjadjaran-Rumah Sakit Dr. Hasan Sadikin Bandung, jalan Pasteur 38 Bandung, mobile 08122022577, e-mail diahthyas@, yahoo.com 


\section{Pendahuluan}

Pneumonia merupakan suatu penyakit yang paling sering terjadi pada anak usia di bawah lima tahun (balita) dan penyebab utama kematian lebih dari 2 juta anak tiap tahunnya yang terjadi terutama di negara berkembang. ${ }^{1,2}$ Insidensi pneumonia di negara berkembang pada anak balita sebesar 0,28 episode/anak/tahun, sedangkan di negara maju 0,05 episode/anak/tahun. Diperkirakan terdapat 155 juta kejadian baru pneumonia pada anak balita tiap tahunnya, ${ }^{3-5}$ dan sebanyak $7-13 \%$ menderita pneumonia berat yang dapat mengancam jiwa dan membutuhkan perawatan di rumah sakit. ${ }^{5}$ The United Nation's Millennium Development Goals (MDGs) ke-4 menyatakan bahwa angka kematian balita harus diturunkan sebanyak 2/3nya dari tahun 1990 sampai tahun 2015, termasuk menurunkan angka kematian karena pneumonia, namun penurunan angka kematian ini tampaknya masih jauh dari target. ${ }^{5,6}$ Berdasarkan penelitian Bryce dkk. ${ }^{7}$ tahun 2000 sampai 2003 didapatkan 10,6 juta anak balita meninggal setiap tahun, dan penyebab utama kematian tersebut adalah pneumonia, yaitu sebesar 19\%. Case fatality rate pneumonia yang mendapat perawatan di rumah sakit sebesar 8,7-47\%. Faktor prediktor yang meningkatkan kematian pneumonia antara lain head nodding, penurunan kesadaran, pucat, serta leukosit abnormal, ${ }^{8}$ namun faktor risiko tersebut masih berbeda antara penelitian satu dan yang lainnya.

Penelitian ini bertujuan untuk mengetahui angka kematian anak balita yang dirawat dengan pneumonia dan faktor risiko yang meningkatkan angka kematian penderita tersebut.

\section{Metode}

Penelitian deskriptifanalitik dengan desain potong lintang ini dilakukan pada bulan November 2007 sampai Januari 2009 di Rumah Sakit Dr. Hasan Sadikin Bandung pada anak berusia 1-59 bulan yang dirawat dengan pneumonia dan bertempat tinggal di Bandung. Persetujuan secara tertulis diperoleh dari orangtua/wali sebelum dilakukan anamnesis serta pemeriksaan fisis dan penunjang. Persetujuan didapat dari Komite Etik Penelitian Kesehatan Fakultas Kedokteran Unpad Bandung.

Pada semua subjek ini dilakukan pencatatan tanggal lahir, jenis kelamin, alamat, berat badan lahir, riwayat prematuritas, riwayat pemberian air susu ibu (ASI), riwayat perawatan sebelumnya, riwayat perawatan anak di tempat penitipan anak, jumlah penghuni rumah, paparan asap rokok dan asap dari proses memasak, riwayat pemberian antibiotik, obat herbal/jamu dan steroid sistemik, riwayat imunisasi untuk pneumococcus, riwayat human immunodeficiensy virus (HIV), kelainan jantung,penyakit thalasemia, operasisplenektomi, asma, keganasan, serta penyakit paru kronik, hati, ginjal, dan diabetes melitus. Pemeriksaan fisis terdiri atas febris, takipnea, serta tarikan dinding dada. Pemeriksaan antropometri subjek dilakukan dengan cara mengukur tinggi serta berat badan anak, dan penentuan status gizi berdasarkan berat badan terhadap tinggi badan pada kurva Z-score World Health Organization (WHO). Pemeriksaan penunjang terdiri atas pemeriksaan hemoglobin, leukosit, hematokrit, trombosit, serta $\mathrm{C}$-reactive protein (CRP), kultur darah, dan foto toraks. Nilai CRP dikatakan meningkat bila $>6$ dan dikatakan leukositosis bila jumlah leukosit $>15.500 / \mathrm{mm}^{3}$. Diagnosis pneumonia berat berdasarkan febris, takipnea, dan retraksi dinding dada. Pembagian derajat berat pneumonia berdasarkan klasifikasi pneumonia oleh WHO, yaitu pneumonia sangat berat bila didapatkan takipnea, tarikan dinding dada, dan terdapat tanda bahaya (sianosis sentral, distres napas berat seperti head nodding dan tidak dapat minum), sedangkan pneumonia berat yaitu takipnea disertai tarikan dinding dada. ${ }^{9}$ Kriteria napas cepat yaitu laju pernapasan $\geq 60 \mathrm{x} /$ menit pada bayi $<2$ bulan, $\geq 50 \mathrm{x} /$ menit pada bayi $2-11$ bulan, dan $\geq 40 \mathrm{x} /$ menit pada anak berusia $1-5$ tahun. ${ }^{1,9}$

Pada penelitian ini ditentukan angka kematian pneumonia serta hubungan antara faktor risiko dan kematian akibat pneumonia. Data dianalisis dengan program SPSS 17, dengan menggunakan Fisher's Exact Test dan Pearson chi-kuadrat, dan dikatakan bermakna jika $\mathrm{p}<0,05$. Odd ratio (OR) ditentukan dengan mepergunakan interval kepercayaan (IK) 95\%. Untuk menguji berbagai faktor risiko secara bersamaan digunakan analisis multivariat regresi logistik.

\section{Hasil}

Selama 15 bulan periode penelitian diperoleh 318 subjek yang dirawat dengan diagnosis pneumonia, terdiri atas 163 (51,3\%) laki-laki dan 155 (48,7\%) perempuan. Berbagai faktor risiko dari penyebab kematian pada pneumonia berat, meliputi usia, jenis kelamin, derajat penyakit pneumonia, berat badan lahir, prematuritas, kelainan jantung, asma, tuberkulosis, malnutrisi, jumlah penghuni rumah, perokok pasif, pemberian antibiotik sebelumnya, dan pemberian ASI dicatat (Tabel 1). Sebanyak $237(74,5 \%)$ anak berusia $\leq 12$ bulan. Diagnosis pneumonia berat $70,8 \%$. Dua puluh tiga penderita (7,2\%) meninggal selama masa perawatan, 20/23 penderita pneumonia sangat berat $(\mathrm{p}<0,001)$ dan $65 \%$ meninggal dengan lama perawatan $<48$ jam. 
Diah Asri Wulandari: Kematian Akibat Pneumonia Berat pada Anak Balita

Tabel 1 Faktor Risiko Kematian karena Pneumonia Berat

\begin{tabular}{|c|c|c|c|c|}
\hline Faktor Risiko & Jumlah & Survivor (n\%) & Kematian (n\%) & p \\
\hline \multicolumn{5}{|l|}{ Usia (bulan) } \\
\hline$\leq 12$ & 237 & $218(92)$ & $19(8)$ & $0,356^{*}$ \\
\hline$>12-<59$ & 81 & $77(95,1)$ & $4(4,9)$ & \\
\hline \multicolumn{5}{|l|}{ Jenis kelamin } \\
\hline Laki-laki & 163 & $153(93,9)$ & $10(6,1)$ & $0,438 *$ \\
\hline Perempuan & 155 & $142(91,6)$ & $13(8,4)$ & \\
\hline \multicolumn{5}{|l|}{ Pneumonia } \\
\hline Sangat berat ${ }^{\S}$ & 93 & $73(78,5)$ & $20(21,5)$ & $<0,001 *$ \\
\hline Berat & 225 & $222(98,7)$ & $3(1,3)$ & \\
\hline \multicolumn{5}{|l|}{ Berat lahir (gram) } \\
\hline$<2.500$ & 49 & $46(93,9)$ & $3(6,1)$ & $1,000 * *$ \\
\hline$\geq 2.500$ & 269 & $249(92,6)$ & $20(7,4)$ & \\
\hline \multicolumn{5}{|l|}{ Prematur } \\
\hline $\mathrm{Ya}$ & 40 & $38(95)$ & $2(5)$ & $1,000 * *$ \\
\hline Tidak & 277 & $257(92,8)$ & $20(7,2)$ & \\
\hline \multicolumn{5}{|l|}{ Tuberkulosis: } \\
\hline $\mathrm{Ya}$ & 18 & $16(88,9)$ & $2(11,1)$ & $0,380 * *$ \\
\hline Tidak & 300 & $279(93)$ & $21(7)$ & \\
\hline \multicolumn{5}{|l|}{ Asma } \\
\hline $\mathrm{Ya}$ & 23 & $21(91,3)$ & $2(8,7)$ & $0,677 * *$ \\
\hline Tidak & 295 & $274(92,9)$ & $21(7,1)$ & \\
\hline \multicolumn{5}{|l|}{ Kelainan jantung bawaan } \\
\hline $\mathrm{Ya}$ & 28 & $21(75)$ & $7(25)$ & $0,002 * *$ \\
\hline Tidak & 290 & $274(94,5)$ & $16(5,5)$ & \\
\hline \multicolumn{5}{|l|}{ Merokok pasif } \\
\hline $\mathrm{Ya}$ & 241 & $220(91,3)$ & $21(8,7)$ & $0,071 *$ \\
\hline Tidak & 77 & $75(97,4)$ & $2(2,6)$ & \\
\hline \multicolumn{5}{|l|}{ Malnutrisi } \\
\hline $\mathrm{Ya}$ & 68 & $60(88,2)$ & $8(11,8)$ & $0,115^{* *}$ \\
\hline Tidak & 250 & $235(94)$ & $15(6)$ & \\
\hline \multicolumn{5}{|l|}{ Penghuni rumah } \\
\hline$>5$ orang & 154 & $142(92,2)$ & $12(7,8)$ & $0,709 *$ \\
\hline$\leq 5$ orang & 64 & $53(93,3)$ & $11(6,7)$ & \\
\hline \multicolumn{5}{|c|}{ Pemberian antibiotik sebelumnya } \\
\hline Ya & 146 & $135(92,5)$ & $11(7,5)$ & $0,871 * *$ \\
\hline Tidak & 170 & $158(92,9)$ & $12(7,1)$ & \\
\hline \multicolumn{5}{|l|}{ ASI } \\
\hline Ya & 253 & $234(92,5)$ & $19(7,5)$ & $0,776^{* *}$ \\
\hline Tidak & 57 & $54(94,7)$ & $3(5,3)$ & \\
\hline Jumlah & 318 & $295(92,8)$ & $23(7,2)$ & \\
\hline
\end{tabular}


Tabel 2 Gambaran Foto Toraks Penderita Pneumonia

\begin{tabular}{lccc}
\hline \multicolumn{1}{c}{ Gambaran Foto Toraks } & n & Survivor & Meninggal \\
\hline Infiltrat & 304 & 288 & 16 \\
Konsolidasi & 2 & 1 & 1 \\
Pneumatokel & 2 & 1 & 1 \\
Efusi pleura & 2 & 1 & 1 \\
Tidak dilakukan pemeriksaan & 8 & 4 & 4 \\
\hline
\end{tabular}

Kelainan jantung didiagnosis pada 28 anak, 7 di antaranya meninggal dunia $(\mathrm{p}=0,002)$. Tidak ada satupun subjek yang menderita HIV, thalassemia, splenektomi, keganasan, penyakit paru kronik, hati, ginjal, dan kencing manis, serta mendapat imunisasi pneumococcus. Semua keluarga subjek penelitian menggunakan kompor gas untuk proses memasak dan tidak ada riwayat penggunaan jamu sebelumnya. Faktor risiko lain seperti malnutrisi, perokok pasif, jumlah penghuni rumah, pemberian antibiotik sebelumnya, maupun pemberian ASI tidak menunjukkan hasil bermakna (Tabel 1).

Hasil pemeriksaan laboratorium didapatkan CRP $>6$ pada 199 anak, 9 di antaranya meninggal dunia $(p=0,056)$, sedangkan kejadian leukositosis $\left(>15.500 / \mathrm{mm}^{3}\right)$ didapatkan pada 125 anak, dan 16 anak meninggal dengan leukositosis $(\mathrm{p}=0,002)$. Pemeriksaan laboratorium tidak dilakukan pada beberapa subjek oleh karena kondisi penderita, ataupun deviasi protokol.

Pemeriksaan foto toraks pada 310 penderita menunjukkan hasil abnormal, 8 penderita tidak dilakukan pemeriksaan foto toraks, 4 di antaranya meninggal dunia sebelum pemeriksaan radiologi dapat dilakukan, dan sisanya menolak dilakukan pemeriksaan foto toraks (Tabel 2).

Pemeriksaan kultur darah pada $111(34,9 \%)$ penderita menunjukkan pertumbuhan bakteri baik bakteri tunggal maupun multipel ( $>1$ bakteri). Hasil kultur yang paling banyak Staphylococcus

Tabel 3 Perbandingan Jenis Mikroorganisme pada Survivor dan Meninggal

\begin{tabular}{lcc}
\hline \multicolumn{1}{c}{ Mikroorganisme } & Survivor & Meninggal \\
\hline Staphylococcus epidermidis & 45 & 4 \\
Staphylococcus aureus & 10 & 2 \\
Enterobacter aerogenes & 9 & 2 \\
Bacillus sp & 6 & 0 \\
Klebsiela pneumoniae & 4 & 0 \\
Pseudomonas aeroginosa & 4 & 0 \\
Moraxella sp & 3 & 0 \\
Streptococcus viridans & 1 & 0 \\
Streptococcus pneumoniae & 0 & 1 \\
Proteus sp & 1 & 0 \\
Serratia sp & 1 & 0 \\
Escherichia coli & 1 & 0 \\
Burkholderia cepucea & 1 & 0 \\
Acinetobacter baumannii & 1 & 0 \\
Haemophillus influenzae & 0 & 1 \\
Staphylococcus saprophyticus dan & 23 & 1 \\
Staphylococcus sp & & 12 \\
Tidak ada pertumbuhan bakteri & & \\
\hline
\end{tabular}


Tabel 4 Analisis Multivariat Faktor Risiko Kematian karena Pneumonia

\begin{tabular}{lcc}
\hline & $\mathrm{p}^{*}$ & OR $(95 \% \mathrm{IK})$ \\
\hline $\begin{array}{l}\text { Pneumonia sangat } \\
\text { berat }\end{array}$ & $<0,001$ & $20,3(5,855-70,197)$ \\
$\begin{array}{l}\text { Penyakit jantung } \\
\text { bawaan }\end{array}$ & 0,002 & $5,7(2,115-15,407)$ \\
Leukositosis & 0,002 & $3,9(1,547-9,727)$ \\
\hline
\end{tabular}

*: Pearson chi square

epidermidis. Dari dua puluh tiga penderita yang meninggal dunia, 12 penderita di antaranya tidak menunjukkan pertumbuhan bakteri, sedangkan 11 penderita sisanya memperlihatkan pertumbuhan bakteri Streptococcus pneumoniae, Haemophilus influenzae, coagulase negative Staphylococcus, Staphylococcus aureus, Enterobacter aerogenes, dan Staphylococcus epidermidis masing-masing 1, 1, 1, 2, 2, dan 4 kultur bakteri (Tabel 3).

Pneumonia sangat berat, leukositosis, serta kelainan jantung bawaan merupakan faktor risiko meningkatkan kematian anak pneumonia yang mendapat perawatan di rumah sakit berdasarkan analisis multivariat (Tabel 4).

\section{Pembahasan}

Hasil pada penelitian ini hampir sama dengan penelitian yang telah dilakukan di Uganda pada anak pneumonia usia di bawah 5 tahun, dilaporkan bahwa $35 \%$ subjek menderita pneumonia sangat berat, 55,4\% terjadi pada usia kurang dari 12 bulan, hasil kultur darah positif pada $15,9 \%$ dan kematian terjadi pada $15,3 \% .{ }^{10}$ Hasil bakteri dari kultur darah sebanyak $10-30 \%,{ }^{11}$ pada penelitian ini hasil bakteri dari kultur darah yaitu 34,9\%. Hasil paling banyak yaitu coagulase negative Staphylococcus (CoNS), meliputi Staphylococcus epidermidis, Staphylococcus saphrophyticus, dan Staphylococcus spp sebagai bakteri komensal kulit, namun dapat merupakan kuman nokosomial terutama bila terjadi di ruang perawatan intensif. Bakteri CoNS dapat dipertimbangkan sebagai kuman penyebab infeksi bila ditemukan kuman yang sama dari dua bahan pemeriksaan yang berbeda, ${ }^{12}$ tetapi penelitian ini hanya mengambil bahan pemeriksaan untuk kultur darah dari satu tempat.

Penelitian yang telah dilakukan oleh Tiewsoh dkk. ${ }^{8}$ menunjukkan head nooding, penurunan kesadaran, nilai leukosit abnormal, dan juga pucat merupakan faktor risiko kematian pneumonia anak usia $<5$ tahun, sedangkan kelainan jantung bawaan, diare, dan malnutrisi merupakan faktor yang meningkatkan lama perawatan di rumah sakit, penggantian antibiotik, serta penggunaan ventilator mekanik. Penelitian yang dilakukan oleh Nantanda dkk. ${ }^{10}$ mendapatkan hasil bahwa faktor yang dapat meningkatkan kematian pada pneumonia anak usia $<5$ tahun yaitu pneumonia yang sangat berat (OR 12,5; 95\% IK: 2,5-65,8), serta hipoksemia (OR 4,9; 95\% IK 1,2-19,5). Penelitian ini memperlihatkan hasil yang sama, pneumonia sangat berat ditandai head nooding, penurunan kesadaran, serta sianosis merupakan faktor yang dapat meningkatkan kematian pada pneumonia (OR 20,3; 95\%IK 5,855-70,197). Riwayat prematur dan berat badan lahir rendah, serta faktor demografi misalnya paparan asap rokok maupun kepadatan dalam rumah, tidak menunjukkan hubungan yang bermakna dengan kematian pada pneumonia. Hasil yang sama juga dilaporkan pada penelitian terdahulu. ${ }^{8}$ Beberapa penelitian lain anak yang tidak mendapat ASI meningkatkan kejadian pneumonia berat sebesar 1,5-2,6 kali dan dapat meningkatkan penggunaan ventilator, serta meningkatkan kematian sebesar $3,2-5,7$ kali. ${ }^{8}$ Malnutrisi terutama malnutrisi yang berat menunjukkan OR 16,5; 95\%IK 4,2-65,5; juga mengingkatkan kematian pada pneumonia oleh karena penurunan respons imun terhadap infeksi. ${ }^{10,13}$ Pada penelitian ini tidak didapatkan peningkatan risiko kematian karena pneumonia pada anak yang tidak mendapatkan ASI maupun malnutrisi. Hal tersebut kemungkinan disebabkan karena pemberian ASI pada penelitian ini bukan merupakan ASI ekslusif selama 6 bulan dan pada penderita community acquired pneumonia (CAP) yang dirawat jarang dengan malnutrisi berat.

Penelitian yang dilaksanakan di Brazil dan Thailand memperlihatkan penyakit jantung dan penyakit kronik mampu meningkatkan kematian karena pneumonia, ${ }^{13}$ hal tersebut didukung pada penelitian ini yang menyatakan penyakit jantung bawaan meningkatkan kematian balita dengan pneumonia $(\mathrm{p}=0,002$; OR 5,7 ; $95 \%$ IK $2,115-$ 15,407).

Nilai CRP yang tinggi berhubungan dengan peningkatan risiko kematian pada pneumonia, ${ }^{14}$ tetapi pada penelitian ini peningkatan nilai CRP tidak meningkatkan kematian pneumonia. Nilai CRP yang tinggi dapat diakibatkan banyak hal selain oleh infeksi bakteri (bacterial pneumonia), sehingga penilaian harus digabungkan dengan parameter klinis dan pemeriksaan lainnya. ${ }^{14}$ Nilai leukosit yang tinggi biasanya ditemukan pada pneumonia bakterial, 26\% menunjukkan jumlah leukosit $>20.000 / \mathrm{mm}^{3}{ }^{11}$ Pada penelitian, $39,3 \%$ subjek memiliki jumlah leukosit $>15.500 / \mathrm{mm}^{3}$ dan leukositosis tidak meningkatkan kematian namun sebagai marker pada balita yang menderita pneumonia $(\mathrm{p}=0,002$; OR 3,9 : $95 \% \mathrm{IK}$ 1,547- 
9,727). Simpulan, kematian karena pneumonia berat masih cukup tinggi. Pneumonia yang sangat berat, kelainan jantung bawaan, dan leukositosis merupakan faktor risiko yang bisa meningkatkan kematian anak balita dengan pneumonia.

\section{Daftar Pustaka}

1. The United Nations Children's Fund (UNICEF)/World Health Organization (WHO). Pneumonia the forgotten killer of children. New York: WHO Press; 2006.

2. Lakhanpaul M, Atkinson M, Stephenson T. Community acquired pneumonia in children: a clinical update. Arch Dis Child Educ Practed. 2004;89(2):29-34.

3. Theodoratou E, Al-Jilaihawi S, Woodward F, Ferguson J, Jhass A, Balliet M, dkk. The effect of case management on childhood pneumonia mortality in developing countries. Int J Epidemiol. 2010;39(Suppl 1):i151-71.

4. Rudan I, Boschi-Pinto C, Biloglav Z, Mulholland K, Campbell H. Epidemiology and etiology of childhood pneumonia. WHO Bul. 2008;86(5):408-16.

5. Rudan I, El Arifeen S, Bhutta AZ, Black RE, Brooks A, Chan KY, dkk. Setting research priorities to reduce global mortality from childhood pneumonia by 2015 . PLOS Med. 2011;8(9):E1001099.

6. United Nation. The Millennium Development
Goals Report 2010. New York: United Nation; 2010.

7. Bryce J, Boschi-Pinto C, Shibuya K, Black RE. WHO estimates of the causes of death in children. Lancet. 2005;365(9465):1147-52.

8. Tiewsoh K, Lodha R, Pandey RM, Broor S, Kalaivani M, Kabra SK. Factors determining the outcome of children hospitalized with severe pneumonia. BMC Pediatr. 2009;9(15):1-8.

9. WHO. Cough and difficult breathing. Pocket book of hospital care for children. Genewa: WHO Press; 2005.

10. Nantanda R, Hildenwall H,Peterson S, KaddeMulindwa D, Kalyesubula I, Tumwine JK. Bacterial aetiology and outcome in children with severe pneumonia in Uganda. Ann Trop Paediatir. 2008;28(4):253-60.

11. Sandora TJ, Harper MB. Pneumonia in hospitalized children. Pediatr Clin North Am. 2005;52(4):1059-81.

12. Venkatesh MP, Placencia F, Weisman LE. Coagulase-negative staphylococcal infections in the neonate and child: an update. Semin Pediatr Infect Dis. 2006;17(3):120-7.

13. Narayanan M, Falade AG. Clinical risk factors for death in children with pneumonia. International child health review collaboration [diunduh 4 Februari 2012]. Tersedia dari: http://www.ichrc.org.

14. Luna CM. C-reactive protein in pneumonia: let me try again. Chest. 2004;125(4):1192-5. 